\title{
Developmental Dislocation of the Hip Successfully Treated by Preoperative Traction and Medial Open Reduction: A 22-year Mean Followup
}

\author{
P. Farsetti MD, R. Caterini MD, V. Potenza MD, \\ E. Ippolito MD
}

Received: 14 October 2014/ Accepted: 13 March 2015/Published online: 1 April 2015

(C) The Association of Bone and Joint Surgeons (B) 2015

\begin{abstract}
Background During the last 35 years, the medial approach has been reported more frequently than the anterior approach for open reduction of developmental dislocation of the hip (DDH), however, few studies have followed children treated by medial open reduction to adulthood.

Questions/purposes The purposes of our study were: (1) to assess the development of 71 completely dislocated hips after medial open reduction, the incidence of additional surgery and avascular necrosis during the followup period, and the long-term radiographic and functional results; and (2) to compare our results with those obtained by others who performed open reduction either by the medial or anterior approach.

Patients and Methods We retrospectively evaluated, after the end of growth, 71 hips in 52 patients who underwent open reduction by the medial approach. The mean age of the patients was 16 months (range, 3-36 months). After surgery, the hips were immobilized in $100^{\circ}$ flexion, $60^{\circ}$

Each author certifies that he or she, or a member of his or her immediate family, has no funding or commercial associations (eg, consultancies, stock ownership, equity interest, patent/licensing arrangements, etc) that might pose a conflict of interest in connection with the submitted article.

All ICMJE Conflict of Interest Forms for authors and Clinical Orthopaedics and Related Research ${ }^{\mathbb{R}}$ editors and board members are on file with the publication and can be viewed on request. Each author certifies that his or her institution approved the human protocol for this investigation, that all investigations were conducted in conformity with ethical principles of research, and that informed consent for participation in the study was obtained.
\end{abstract}

P. Farsetti, R. Caterini, V. Potenza, E. Ippolito ( $\square)$

Department of Orthopaedic Surgery, University of

"Tor Vergata", Viale Oxford, 81, 00133 Rome, Italy

e-mail: ippolito@med.uniroma2.it abduction, and neutral rotation for an average of 6 months. All patients had staged clinical and radiographic followups until skeletal maturity. The length of followup averaged 22 years (range, 13-32 years).

Results In all the surgically treated hips, the acetabular index normalized by the end of growth, the incidence of avascular necrosis was $18 \%$, and additional surgery was required in $15 \%$ of our cases. At the last followup, $93 \%$ of the hips were classified as Severin Classes I or II and $7 \%$ as Class III; $76 \%$ of the hips had an excellent result, $17 \%$ had a good result, and $7 \%$ had a fair result according to the McKay scale as modified by Barrett and colleagues.

Conclusions Open reduction of DDH through a medial approach provided good long-term radiographic and functional results in patients 3 to 36 months old and it was the only surgery performed in $85 \%$ of our cases. Future comparative studies are needed to confirm our results, especially in older children.

Level of evidence Level IV, therapeutic study.

\section{Introduction}

The incidence of complete dislocation of the hip as the final step of developmental dysplasia of the hip (DDH) has decreased attributable mostly to early diagnosis and treatment [8, 15, 19, 28, 29, 55, 87]; however, cases of complete dislocation, requiring open reduction still occur.

Open reduction for treatment of a complete dislocation of the hip may be performed either by an anterior or medial approach. During the last 36 years, the anterior approach has been reported less frequently $[1,10,17,18,20,23,25$, $30,31,47,58,70,71,73,79,80]$ than the medial approach $[4,6,7,11,16,21,22,33,36,37,39,40,46,48-50,52-54$, $60,69,77,78,85,88]$, especially in younger children. 
Independently of the approach, various complications have been reported and in some of the previously cited series, the incidence of complications is high.

It is known that the final result of DDH after open reduction can be evaluated only when musculoskeletal growth is completed [81], but to our knowledge, there is a paucity of studies including skeletally mature patients [5, 18, 30, 33, 39, 52, 71, 78-80].

The purposes of our study were: (1) to assess the development of completely dislocated hips after medial open reduction, the incidence of additional surgery and avascular necrosis during the followup period, and the long-term radiographic and functional results; and (2) to compare our results with those obtained by others who used either medial or anterior open reduction.

\section{Patients and Methods}

From January 1980 to December 2000, a total of 512 children ranging in age from 2 months to 7 years (mean age, 11 months) underwent treatment for DDH at our institution. Treatment included either bracing, plaster casting, or surgery depending on the evolutive stage of the $\mathrm{DDH}$ and its severity. Whenever open reduction of a hip dislocation was required, we used a medial approach in children up to 36 months old and an anterior approach in older children. One-hundred-sixty-nine consecutive patients (234 hips) who had unreducible complete hip dislocation were treated by or under the direct supervision of the four authors in accordance with the directions of the senior author (EI). All patients who had started any treatment elsewhere, including prior bracing or use of a Pavlik harness, and patients with teratologic, neuromuscular, or syndromic dislocation, were not included in our study.

Since 1980, the protocol at our institution for managing unreducible, complete developmental hip dislocation consisted of traction in bed for 4 weeks; attempt at closed reduction with gentle maneuvers using general anesthesia; and whenever closed reduction was not achieved or there was concern that it could be unstable in $100^{\circ}$ flexion, $60^{\circ}$ abduction, and neutral rotation, an open reduction was performed at the same time.

Of 169 patients with unreducible hip dislocations, 82 patients (112 hips) had successful closed reduction under general anesthesia. Closed reduction was considered safe when the hip was stable at $100^{\circ}$ flexion, $60^{\circ}$ abduction, and in neutral rotation [45]. Arthrography was not performed routinely in hips that had closed reduction. The patients ranged from 3 to 21 months old (mean age, 9 months).

Eighty-seven patients (122 hips) in whom closed reduction either was not achieved or was thought to be unstable in $100^{\circ}$ flexion, $60^{\circ}$ abduction, and neutral rotation had open reduction through a medial approach as described by Weinstein and Ponseti [85]. A transverse incision was made parallel and $1 \mathrm{~cm}$ distal to the inguinal fold extending from a point just medial to the femoral neurovascular bundle to the medial border of the adductor longus muscle that was isolated and sectioned. The anterior branch of the obturator nerve was identified under the pectineus muscle that was retracted medially. The iliopsoas tendon was identified and sectioned just above the lesser trochanter and the medial circumflex artery and vein were ligated. The articular capsule then was opened along its longitudinal axis and a second perpendicular incision of the capsule was made parallel to the medial border of the acetabulum. The joint was inspected and all the obstacles to the concentric reduction of the femoral head (ligamentum teres, fibrofatty tissue of the pulvinar, transverse acetabular ligament) were removed. The neolimbus (inverted labrum) was never an obstacle to reduction but rather a posterior stabilizer of the femoral head after reduction.

Surgery was performed by one of the four authors; residents were part of the surgical team but they did not perform the medial open reduction independently.

The 87 patients (122 hips) who had medial open reduction were enrolled in our retrospective study. Twelve patients (16 hips) were lost to followup because they had moved elsewhere and it was not possible to contact them. We were able to locate 75 patients (106 hips), but only 57 (79 hips) agreed to return for clinical and radiographic followups. Eighteen patients ( 27 hips) contacted by telephone declined our invitation because they lived far from our hospital, but 10 of them (14 hips) agreed to send recent radiographs of their pelvis. Of the 57 patients (79 hips) who came to the hospital, five (eight hips) did not have initial radiographs in their records whereas 52 (71 hips) had a full set of radiographs taken according to our followup schedule and they were included in the statistical analysis of the study. The eight patients (14 hips) who had only telephone interview, the 10 patients who had telephone interview and who mailed recent radiographs, and the five patients who came to the hospital but had an incomplete set of radiographs were included in the final followup but were excluded from the statistical analysis of the study (Fig. 1).

The age of the patients at the time of diagnosis ranged from 3 to 36 months (mean age, 16 months). In all cases, medial open reduction was performed after the patient underwent 4 weeks of traction after diagnosis. Forty-two patients were girls and 10 were boys. Forty left hips and 31 right hips were dislocated. Twenty-five patients had bilateral DDH, but in six of the 25 , one dislocated hip had successful closed reduction. We divided the 52 patients (71 hips) who underwent medial open reduction into three age groups to evaluate the influence of age at surgery on the 


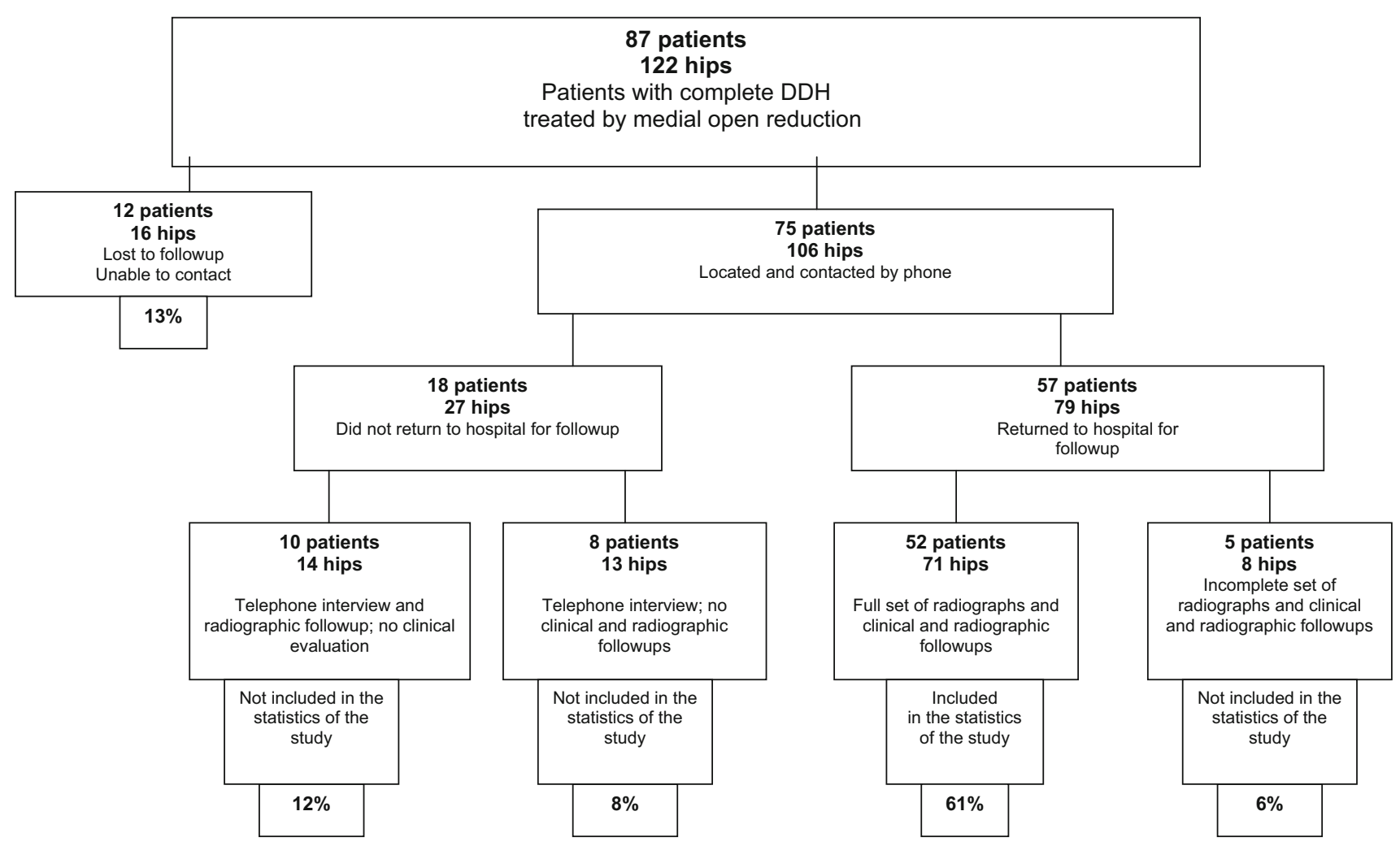

Fig. 1 The flow-diagram of the patients enrolled in the study is shown.

development of the hip during growth and on the complication rate and long-term results.

All the patients underwent 4 weeks of traction before surgery. To obtain valid traction, a hip spica cast was applied to the contralateral hip. Two strings were sealed to the back of the plaster cast that was firmly anchored to the head of the bed [41]. Skin traction then was applied to the dislocated hip in approximately $20^{\circ}$ flexion, $20^{\circ}$ abduction, and $20^{\circ}$ external rotation. Since 1989 , owing to increased hospital costs, traction has been an outpatient procedure and it is maintained by the patient afterward at home. Before traction, the height of the dislocation was graded according to Gibson and Benson [27] (Table 1).

After surgery, a bilateral hip spica cast was applied in $100^{\circ}$ flexion, $60^{\circ}$ abduction, and neutral rotation. Six weeks later, radiographs were taken and a second bilateral spica cast, in the same position, was applied for 6 more weeks; thereafter, an abduction brace was applied full time for an average of 4 months. The patient then was allowed to crawl and walk freely, keeping the brace on only at night for 2 more years. Two hips in two patients redislocated while the patients were wearing the plaster cast, and a second medial open reduction stabilized with a $1.8-\mathrm{mm}$ thick K-wire crossing the joint was performed in each patient.
After cast removal, patients had clinical and radiographic examinations at regular intervals of 3, 6, 12, 18, and 24 months, then once a year until 7 years of age, and then once every 2 years until menarche in girls and puberty in boys. Families of six patients (nine hips) refused the last followup radiographs that should have been taken at puberty.

The senior author (EI) measured the following radiographic parameters once a week for 3 consecutive weeks using a computer metric program: the (1) acetabular index [43]; (2) lateral instability index [68]; (3) Wiberg angle [86]; (4) anterior coverage of the femoral head [42]; (5) Sharp angle [67], and the (6) neck-shaft and femoral anteversion angles [75]. The intraobserver $\kappa$-score was 0.881 .

Avascular necrosis (AVN) of the proximal femoral epiphysis was classified according to the Bucholz and Ogden classification [13] modified by Morcuende et al. [50].

Additional surgery was performed either in symptomatic cases or in cases in which the radiographic parameters were persistently altered, with risk of subluxation [81].

At the last followup, clinical results were graded using the criteria of McKay modified by Barrett et al. [9] and radiographic results were classified according to Severin [66]. 
Table 1. Three patient age groups

\begin{tabular}{|c|c|c|c|}
\hline \multirow{2}{*}{$\begin{array}{l}\text { Dislocation height } \\
\text { according to Gibson and } \\
\text { Benson classification [27] }\end{array}$} & $\begin{array}{l}\text { Group } 1 \\
\text { Age 3-12 months }\end{array}$ & $\begin{array}{l}\text { Group } 2 \\
\text { Age } 13-24 \text { months }\end{array}$ & $\begin{array}{l}\text { Group } 3 \\
\text { Age } 25-36 \text { months }\end{array}$ \\
\hline & $\begin{array}{l}22 \text { patients*/26 hips } \\
\text { (9 bilateral; } 13 \text { unilateral) }\end{array}$ & $\begin{array}{l}19 \text { patients }^{\dagger} / 27 \text { hips } \\
\text { (9 bilateral; } 10 \text { unilateral) }\end{array}$ & $\begin{array}{l}11 \text { patients } / 18 \text { hips } \\
\text { ( } 7 \text { bilateral; } 4 \text { unilateral) }\end{array}$ \\
\hline High & 5 & 13 & 14 \\
\hline Intermediate & 13 & 8 & 4 \\
\hline Low & 8 & 6 & 0 \\
\hline
\end{tabular}

* One hip in each of five patients with bilateral DDH had successful closed reduction; ${ }^{\dagger}$ one hip in one patient with bilateral DDH had successful closed reduction; DDH = developmental dislocation of the hip.

Statistical analysis was performed using SPSS Version 15.0 (SPSS Inc, Chicago, IL, USA). Descriptive statistics consisted of the mean \pm SD for parameters with Gaussian distributions (after confirmation with the KolmogorovSmirnov test) or median and range (minimum-maximum) for non-Gaussian parameters. Comparison among groups of Gaussian parameters was performed with one-way plus multiple-comparison ANOVA using the Bonferroni and Kruskal-Wallis tests for non-Gaussian parameters. For numbers, frequencies (\%), or categoric variables, comparisons among groups were performed with the chi-square test or Fisher's exact test (in a contingency table with cell frequencies less than 5). A $\mathrm{p}$ value less than 0.05 was considered statistically significant.

The length of followup ranged from 13 to 32 years, with an average of 22 years. At final followup, all patients were skeletally mature.

The study was approved by our institutional ethical board.

\section{Results}

At diagnosis, the acetabular index averaged $40^{\circ}$. It improved rapidly during the first year after open reduction and then slowly, reaching a standard value on average 4 years after open reduction (range, 1.6-6 years) (Fig. 2). Improvement in the acetabular index occurred more quickly in patients in Group 1 who were 3 to 12 months old than in the other two groups (Fig. 3). In 28 children with DDH who were 14 months and older, several small centers of ossification developed in the acetabular cartilage which became fully ossified by gradual coalescence of the ossification centers (Fig. 4).

The lateral stability index of Smith et al. [68] always scored within normal limits (0.65-0.87), even when the acetabular index remained abnormal (Fig. 4).

All the children had limited ROM of the hip after weaning from the brace, but all recovered a normal gait. No patient reported any limitations of activities of daily life and 35 patients had become involved in sport activities.
During the followup, 10 patients (11 hips) had additional surgery for a total of 13 procedures (15\%): seven Tönnis periacetabular osteotomies [76], five varus derotation femoral osteotomies, and one distal transfer of the greater trochanter. Before surgery, four patients were symptomatic. Three patients ranging in age from 14 to 15 years with acetabular insufficiency (Wiberg $<20^{\circ}$ ) had a painful limp after prolonged walking or sporting activities. One 13-yearold patient was limping owing to $2.5-\mathrm{cm}$ femoral shortening attributable to Grade III AVN. No statistically significant differences were found between age group and additional surgeries $(p=0.229)$. Three patients had a transient mild limp after the varus derotation femoral osteotomy. No patient required an arthroplasty at the time of the last followup (Table 2).

AVN Grades II to V developed in 13 hips (18.3\%) (Figs. 3, 4). AVN was significantly different among the three groups of patients $(\mathrm{p}=0.002)$ and three levels of dislocation $(p=0.001)$ [27]. AVN developed in one of 22 hips without the ossification center of the femoral head and in 12 of 49 hips with the ossification center. One patient with Grade III AVN had $2 \mathrm{~cm}$ lower limb shortening and he started to limp when he was 10 years old (Table 3).

At the last followup three patients with Grade II AVN who underwent varus derotation femoral osteotomy had a lower limb length discrepancy ranging from $1 \mathrm{~cm}$ to $2 \mathrm{~cm}$; the discrepancy measured $2.5 \mathrm{~cm}$ in the patient with Grade III AVN. In patients with shortening of 2 to $2.5 \mathrm{~cm}$, the limb length discrepancy was well compensated with an insole. No patient reported pain. All patients were fully satisfied with the surgical scar resulting from the medial approach, which in many cases was barely visible.

At clinical evaluation [9], 44 hips (76\%) had an excellent result, 24 (17\%) had a good result, and three (7\%) had a fair result (Table 4). There was a statistically significant difference between age group and clinical results $(\mathrm{p}=0.0001)$. At radiographic evaluation, the Sharp angle was normal in all the hips, with a mean measure of $40^{\circ}$ (range, $38^{\circ}-43^{\circ}$ ); 39 hips $(63 \%)$ were ranked as Severin Class I and 64\% of them were in patients in age Group 1 including the youngest patient at surgery; 27 hips (30\%) 

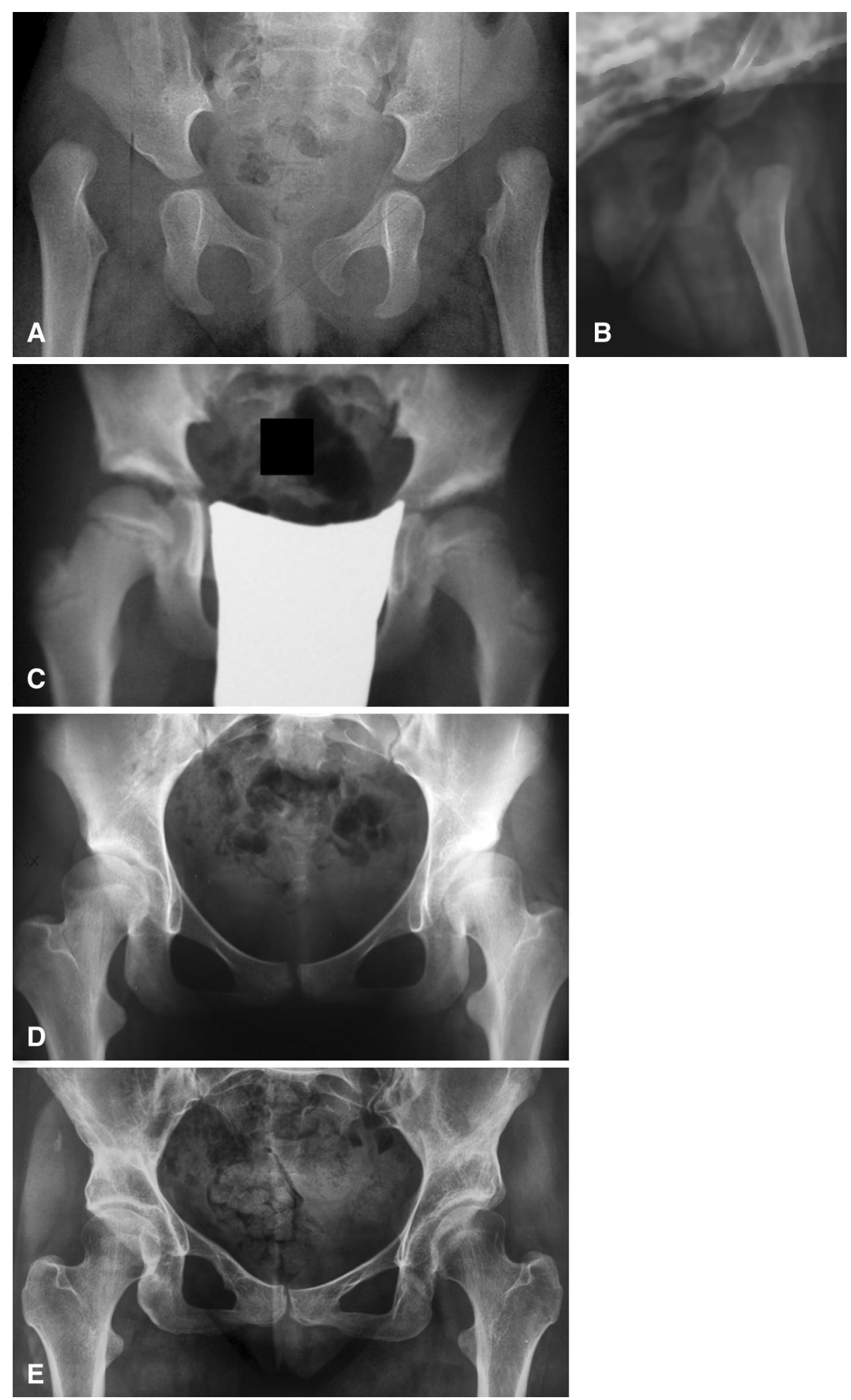

Fig. 2A-E (A) An AP view radiograph shows bilateral high developmental dislocation of the hip in a 13-month-old girl. (B) After 4 weeks in traction, both hips were pulled to a low position. (C) Both hips were well developed, and the acetabular index and Wiberg angle were normal when the patient was 9 years old. (D) At age 15 years, 6 months after menarche, both hips became painful and the
Wiberg angle was abnormal bilaterally. A Tönnis triple pelvic osteotomy was performed with normalization of the Wiberg angle. (E) At the last followup, the patient was 28 years old and both of her hips had an excellent clinical result, with Severin Class I on the right and Class II on the left. 

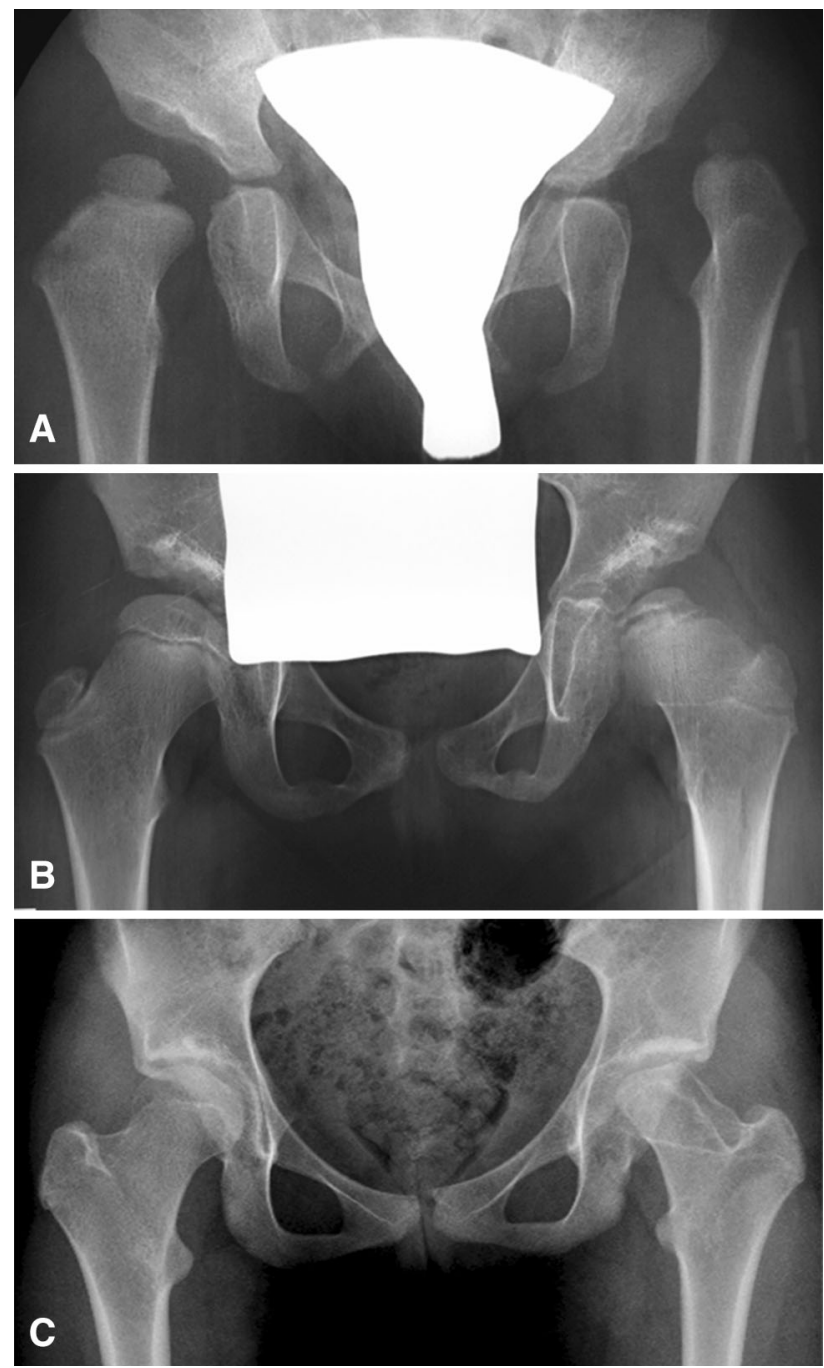

Fig. 3A-C (A) An AP view radiograph shows high developmental dislocation of the left hip and subluxation of the right hip in a 32month-old girl. (B) At age 5 years, 3 years after she underwent medial open reduction of the left hip, Grade III avascular necrosis was evident. (C) At the last followup, the patient was 17 years old. The avascular necrosis was classified as Grade V but the hip had a good clinical result and was scored Severin Class II.

were ranked as Severin Class II whereas five (7\%) were Class III. Three of the six patients who missed the scheduled radiographic followup had their hips ranked as Severin Class III at the last followup (Table 4). There was a statistically significant difference between age group and radiographic results $(\mathrm{p}=0.0001)$.

At the last followup, 20 of 34 hips reduced in patients after 16 months of age $(88.2 \%)$ showed minor radiographic abnormalities of the femoral head consisting of asymmetry and size and shape alteration. In the same cases, moderate deformity of the ossific nucleus of the femoral head was present before open reduction.
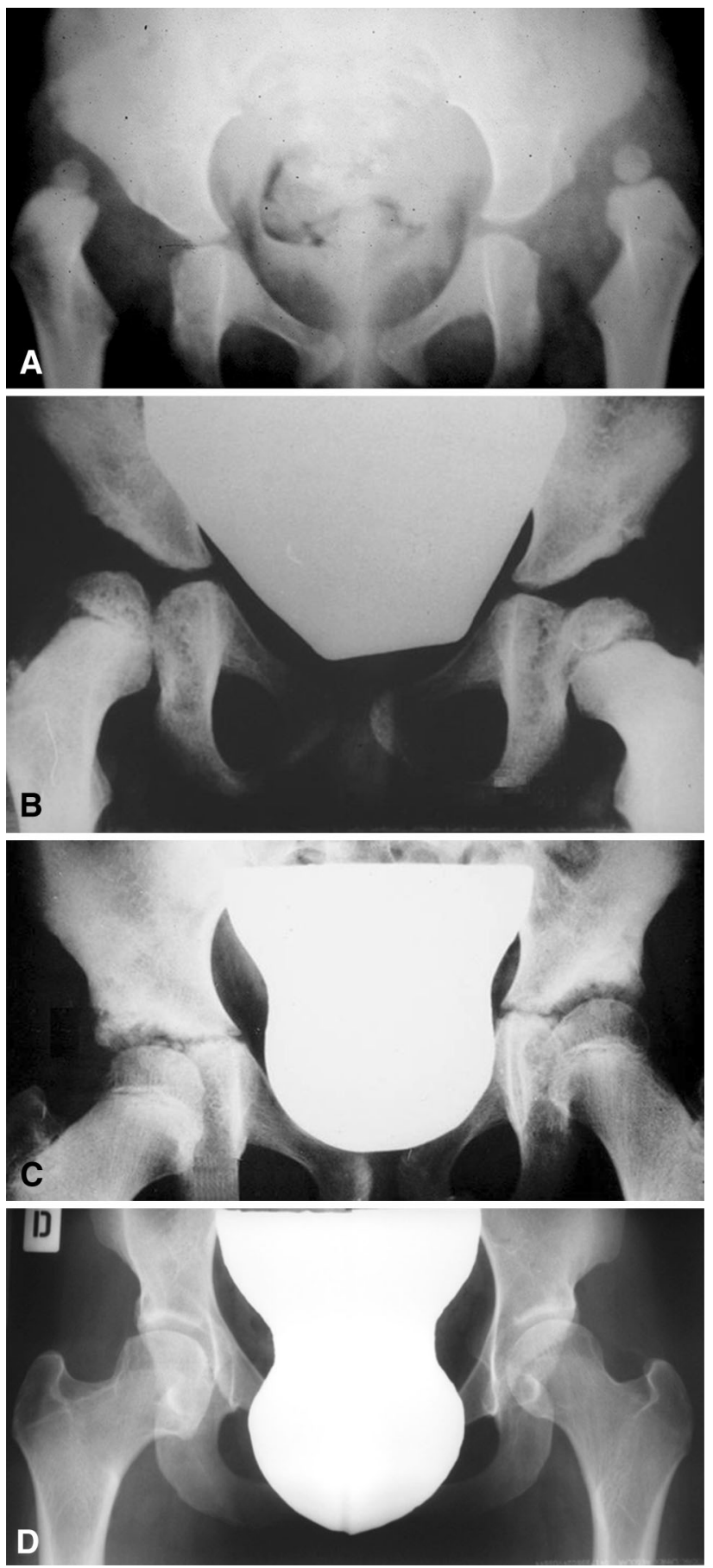

Fig. 4A-D (A) An AP view radiograph shows bilateral developmental dislocation of the hip, which was high on the right and intermediate on the left, in a 36-month-old girl with bilateral DDH. (B) When the patient was 5 years old, 2 years after bilateral medial open reduction, her right hip showed Grade IV avascular necrosis and the acetabular index was abnormal bilaterally, although both hips were clinically and radiographically stable. (C) At age 11 years, the patient's acetabular index had become normal bilaterally. (D) At the last followup, the patient was 32 years old and both of her hips had an excellent clinical result, with Severin Class I on the left and Class II on the right. 
Table 2. Additional surgeries

\begin{tabular}{|c|c|c|c|c|}
\hline Case & $\begin{array}{l}\text { Age of patient } \\
\text { at surgery (years) }\end{array}$ & Diagnosis & $\begin{array}{l}\text { Clinical aspects } \\
\text { before surgery }\end{array}$ & $\begin{array}{l}\text { Type of } \\
\text { surgery }\end{array}$ \\
\hline 1 & 9 & Grade II avascular necrosis & Asymptomatic & Varus derotation femoral osteotomy \\
\hline 2 & 9 & Grade II avascular necrosis & Asymptomatic & Varus derotation femoral osteotomy \\
\hline 3 & 9 & Coxa valga antetorta & Asymptomatic & Varus derotation femoral osteotomy \\
\hline 4 & 10 & Grade II avascular necrosis & Asymptomatic & $\begin{array}{l}\text { Varus derotation femoral osteotomy, } \\
\text { Tönnis osteotomy }\end{array}$ \\
\hline 5 & 11 & Grade II avascular necrosis & Asymptomatic & Tönnis osteotomy \\
\hline 6 & 13 & Grade III avascular necrosis & Limp & Distal transfer of the greater trochanter \\
\hline 7 & 14 & $\begin{array}{l}\text { Acetabular insufficiency } \\
\text { (Wiberg angle }<20^{\circ} \text { ) }\end{array}$ & Asymptomatic & Tönnis osteotomy \\
\hline 8 & 14 & $\begin{array}{l}\text { Acetabular insufficiency } \\
\left(\text { Wiberg angle }<20^{\circ}\right) \text { coxa } \\
\quad \text { valga antetorta }\end{array}$ & Pain & $\begin{array}{l}\text { Varus derotation femoral osteotomy, } \\
\text { Tönnis osteotomy }\end{array}$ \\
\hline 9 & 15 & $\begin{array}{l}\text { Acetabular insufficiency } \\
\text { (Wiberg angle }<20^{\circ} \text { ) }\end{array}$ & Pain & Tönnis osteotomy \\
\hline 10 & $15^{*}$ & $\begin{array}{l}\text { Acetabular insufficiency } \\
\text { (Wiberg angle }<20^{\circ} \text { ) }\end{array}$ & Pain & Tönnis osteotomy \\
\hline 11 & $15^{*}$ & $\begin{array}{l}\text { Acetabular insufficiency } \\
\text { (Wiberg angle }<20^{\circ} \text { ) }\end{array}$ & Pain & Tönnis osteotomy \\
\hline
\end{tabular}

No significant difference between age groups and additional surgery $(\mathrm{p}=0.229)$; 13 procedures in 11 hips $(10$ patients). In Cases 4 and 8 , varus derotation femoral osteotomy and Tönnis periacetabular osteotomy were performed during the same operative session; *same patient had bilateral procedures.

Table 3. Avascular necrosis

\begin{tabular}{llll}
\hline $\begin{array}{l}\text { Age of patient (years) at } \\
\text { radiographic diagnosis }\end{array}$ & Grade* & $\begin{array}{l}\text { Age of patient at } \\
\text { surgery (months) }\end{array}$ & $\begin{array}{l}\text { Height of } \\
\text { dislocation }\end{array}$ \\
\hline 9 & II & 10 & High \\
9 & II & 18 & Intermediate \\
10 & II & 19 & High \\
11 & II & 28 & Intermediate \\
3 & III & 29 & High \\
2.5 & IV & 22 & High \\
3 & IV & 24 & High \\
3.5 & IV & 27 & High \\
3.5 & IV & 27 & High \\
4 & IV & 32 & High \\
4 & IV & 32 & High \\
4 & IV & 36 & High \\
4.5 & V & 34 & Intermediate \\
\hline
\end{tabular}

* Statistically significant difference with patient age at surgery $(\mathrm{p}=0.002)$ and height of dislocation $(\mathrm{p}=0.001)$; Bucholz and Ogden [13] grade modified by Morcuende et al. [50], observed in 13 of 71 hips; six hips with Grade I avascular necrosis not included because avascular necrosis resolved without any long-term sequelae; "same patient with bilateral developmental dislocation of the hip.

Of the 23 patients included in the followup but excluded from the statistics of the study, 18 patients who had a telephone interview affirmed they were doing well without pain or restrictions of physical activity. Ten also mailed recent radiographs of their hips: six hips were ranked Severin Class I, seven were Class II, and one was Class III. The five patients (eight hips) who came to the hospital whose initial radiographs were missing from their records also were asymptomatic and at clinical evaluation, three hips had an excellent result; three had a good result, and two had a fair result. Three hips were ranked Severin Class I, three were Class II, and two were Class III.

\section{Discussion}

This retrospective study shows our 20-year-experience with open medial reduction of complete DDH in patients ranging from 3 to 36 months old. Although medial versus anterior open reduction is debated with complete dislocations [11, 16, 21, 40, 46, 49, 50, 52, 53, 64, 77, 84, 85, 88], open medial reduction after preliminary traction gave us good results. All hips in our patients remained stable after completion of treatment and the acetabular index normalized in all of them. The prevalence of AVN and additional surgery was reasonably low, and the majority of the hips had a high radiographic Severin class at the end of growth.

Our study has several limitations. First, as in all retrospective studies, there is partial patient selection bias. We have statistically evaluated only $61 \%$ of the original cohort 
Table 4. Clinical and radiographic results at the last followup

\begin{tabular}{|c|c|c|c|}
\hline $\begin{array}{l}\text { Group } 1 \\
3-12 \text { months old } \\
22 \text { patient/26 hips }\end{array}$ & $\begin{array}{l}\text { Group } 2 \\
13-24 \text { months old } \\
19 \text { patients } / 27 \text { hips }\end{array}$ & $\begin{array}{l}\text { Group } 3 \\
25-36 \text { months old } \\
11 \text { patients/18 hips }\end{array}$ & $\begin{array}{l}\text { Clinical* and }^{*} \text { and } \\
\text { radiographic } \\
\text { results }\end{array}$ \\
\hline \multicolumn{4}{|l|}{ Clinical results } \\
\hline 26 hips & 13 hips & 5 hips & Excellent $(76 \%)$ \\
\hline 0 & 13 hips & 11 hips & Good (17\%) \\
\hline 0 & 1 hip & 2 hips & Fair $(7 \%)$ \\
\hline \multicolumn{4}{|l|}{ Radiographic results } \\
\hline 25 hips & 10 hips & 4 hips & Class I (63\%) \\
\hline 1 hip & 15 hips & 11 hips & Class II (30\%) \\
\hline 0 & 2 hips & 3 hips & Class III (7\%) \\
\hline
\end{tabular}

Clinical results, $\mathrm{p}=0.0001$; radiographic, $\mathrm{p}=0.0001$; *valuated using McKay scale modified by Barrett et al. [9], and ${ }^{\dagger}$ Severin radiographic class [66].

of patients. However, the overall number of patients who had followups with satisfactory long-term results is $87 \%$ of the original cohort if we include patients who had either telephone interview or partial clinical and radiographic evaluations, although not fulfilling all the criteria to be included in the statistics of the study. The second limitation is an assessment bias because only the senior author (EI) made the radiographic measurements. However, his intraobserver $\kappa$ score was 0.881 which makes his assessment error acceptable. The third limitation is the lack of a control series. However, none of the previously reported long-term followup series after medial open reduction has a control series $[33,39,50,78]$. The fourth limitation is the lack of homogeneity between the three age groups, with the third group including almost 30\% less cases than the other two. However, a similar discrepancy was present in other series of patients with DDH treated by medial open reduction in which the number of children older than 24 months was relatively low [33, 39, 50, 78].

All the hips with DDH in our series were not reducible in flexion and abduction at the time of diagnosis, even in children 3 to 10 months old. For this reason, a more conservative treatment, such as the Pavlik harness or other braces, was not used $[15,29]$.

In our institution, traction has been part of DDH treatment since the early 1960s. Since then, we have continued to use preliminary traction to decrease the risk of complications in case of closed reduction, as reported by others $[24,51,57]$. The effect of preoperative traction has been questioned for surgical treatment of DDH since all the anatomic obstacles to hip reduction are surgically eliminated [35, 59, 64, 82]. Although the percentage of our excellent and good long-term radiographic results, according to the Severin classification, is higher than in other series in which traction was not used $[18,30,33,39,50$,
$71,78-80]$, it is difficult to determine whether preoperative traction served to decrease the complication rate. Inpatient traction is costly $[35,59,82]$; however, more than $1 / 2$ of our patients successfully completed home traction before surgery. The hip spica cast was firmly anchored to the bed ensuring the child's compliance with the traction. The patient's compliance and the amount of traction were supervised twice a week at home by one of our residents.

Early hip subluxation after open reduction and/or redislocation while wearing the plaster cast has been reported in a range of $0 \%$ to $11 \%$ with a mean of $2.4 \%$ for anterior and medial open reductions $[7,10,11,16,18,20,21,23$, $31,37,40,46,50,52,69,70,77-79,88]$. Our patients had a redislocation rate of $2.8 \%$. Since then, hips that were not fully stable at surgery at $100^{\circ}$ flexion, $60^{\circ}$ abduction, and neutral rotation had K-wire fixation [3] to prevent redislocation.

Additional surgery after open reduction is important, and it is related to hip development after open reduction [2]. Its prevalence in patients with DDH who had open reduction by either the anterior or medial approach ranges from $0 \%$ to $100 \%[1,4,6,7,10,11,16,18,20,21,23,25$, $30,31,33,36,37,39,46-50,52-54,58,60,69,71,73,77-$ $80,88]$, and its prevalence in our series was $15 \%$. We believe that a high acetabular index during the years after open reduction is not an indication for a mandatory acetabular procedure like a Pemberton acetabuloplasty or Salter osteotomy if the hip is stable. All our patients' hips showed stable concentric reduction clinically and radiographically, according to the lateral instability index of Smith et al. [68]. Cartilaginous and labral coverage, as evaluated by MRI, may be normal even in cases with delayed acetabular cartilage ossification [34]. The acetabular index improved slowly, especially in our older patients, and took several years to become normal in many children 
who underwent surgery after 14 months old, as reported by others [1, 32, 38, 43]. Moreover, acetabular procedures performed early do not fully guarantee the persistence of normal acetabular coverage to the end of growth, as shown in a long-term followup study by Thomas et al. [74], in which $15 \%$ of the hips were scored Severin Class III and $2 \%$ were Class IV despite the Salter procedure being performed after open reduction. We performed the Tönnis osteotomy on patients ranging from 10 to 15 years old whose hips had an abnormal Wiberg angle. In some of the cases, acetabular coverage was normal before puberty, and we might speculate that acetabular depth failed to increase in proportion to femoral head enlargement owing to the lack of development of the secondary centers of ossification of the acetabulum at puberty [56, 81]. We believe patients with dislocated hips should be followed up radiographically after open reduction until puberty to avoid missing late acetabular insufficiency.

In our series, the incidence of AVN was $18 \%$. Numerous authors have reported an incidence of AVN in patients who had open reduction either by the medial or anterior approach $[10,21,31,37,60,77,88]$ that was lower than the incidence in our series. However, the followups were too short in those series to include all possible cases of AVN since many, especially type 2 , may show up when the patient is 9 to 10 years or older $[13,39,50,69,81]$. In some studies, the AVN rate was high when the ossific nucleus of the femoral head was absent [17, 65]. In our study and others [44, 62], an opposite correlation was found ( $\mathrm{p}=0.002)$.

The proper approach (anterior versus medial) for open reduction of complete DDH continues to be debated. Many authors recommend the medial approach as a procedure that can be performed safely in children younger than 18 to 24 months [24, 27, 28, 30, 32, 34, 35, 37, 41, 43, 44, 84]. We agree with those authors because in patients younger than 24 months, AVN and additional surgery have been reported in patients treated by anterior open reduction at a similar or higher rate than patients treated by medial open reduction [12]. In a recent prospective study of two cohorts of patients with an upper age limit of 24 months [72], one cohort had the medial approach and the other had the anterior approach, and the AVN rate was significantly lower in the medial approach cohort at an average followup of 7 years (12\% versus $18 \%$ ). In our series, the prevalence of AVN in patients younger than 24 months was $9.4 \%$, although in a recent meta-analysis of open reduction by the medial approach, the average prevalence of AVN was $20 \%$ [26]. Anterior open reduction has been recommended in children with complete hip dislocation who are older than 24 months [84]. This same recommendation was made by many authors who advocated medial open reduction in children younger than 24 months [11, 16, 21, 40, 46, 49,
$50,52,53,77,85,88]$. Although we were aware of this general trend in favor of anterior open reduction that provides capsulorrhaphy and avoids medial circumflex vessels, the good preliminary results we obtained in children older than 24 months encouraged us to increase the upper age limit for medial open reduction to 36 months. Moreover, according to the literature, even open reduction by the anterior approach may provide unsatisfactory results in children older than 24 months $[17,18,25,30,33,47,58$, 73, 79, 80]. Schoenecker and Strecker [64] reported two series of patients older than 24 months who had open reduction by the anterior approach. One series of patients had preliminary traction while the others underwent femoral shortening osteotomy. In the first series, AVN developed in $53.8 \%$ of the patients, whereas it was absent in the second series, although in the latter, three of four hips in patients 38 to 40 months old ultimately were ranked as Severin Class III or IV. Galpin et al. [25] reported 14 hips in patients with similar ages who had open reduction by the anterior approach with femoral shortening osteotomy. The AVN rate was only $10 \%$, but $42.8 \%$ of the hips were ranked as Severin Class III. The conclusions that may be drawn from the studies by Schoenecker and Strecker [64] and Galpin et al. [25] are that (1) in children older than 24 months, the anterior approach reduces the AVN rate only if it is associated with femoral shortening osteotomy; and (2) in children older than 24 months, the anterior approach does not prevent unsatisfactory final results according to the Severin classification. We observed a $40 \%$ rate of AVN in children 25 to 36 months old but the final radiographic results, according to the Severin classification, were good in $80 \%$ of cases. However, patients with sequelae of AVN do not show early significant physical disability, although their good function tends to decline with age $[61,81]$.

According to Schoenecker and Strecker [64] and Galpin et al. [25], we might perform an associated femoral shortening osteotomy with medial open reduction to further reduce the rate of AVN in patients 25 to 36 months old.

Long-term followup studies at skeletal maturity are rare in DDH series where patients underwent open reduction either by the anterior $[5,18,30,33,39,50,71]$ or medial approach [78-80]. The Severin classification has been used to evaluate final radiographic results owing to its reliability [14]. In anterior approach series, the average prevalence of AVN is $24 \%$ (range, $7.6 \%-47 \%$ ); the average prevalence of additional surgery is $68.9 \%$ (range, $22.4 \%-100 \%$ ), while the average prevalence of excellent and good radiographic results according to the Severin classification is $73.8 \%$ (range, 33\%-96\%). In medial approach series, the average prevalence of AVN is $28.7 \%$ (range, $9 \%-43 \%$ ); the average prevalence of additional surgery is $35.5 \%$ (range, $17.2 \%-50 \%$ ), while the average prevalence of excellent 
and good radiographic results according to the Severin classification is $62.9 \%$ (range, $45.7 \%-79 \%$ ). In our series, the AVN rate was $8 \%$, additional surgery was $15 \%$, and excellent and good results were $93 \%$ according to the Severin classification. We believe the anterior and medial approaches are comparable; in long-term followups, the rate of AVN is lower in patients who had the anterior approach, mainly with femoral shortening osteotomy, whereas the number of additional surgeries is much lower in patients who had the medial approach. At the last radiographic followup, minor deformities of the femoral head were observed in $88.2 \%$ of the hips in patients who had open reduction after 16 months of age [53]. We might speculate that mild deformity of the femoral head may be caused by minor degrees of AVN not described in any of the current AVN classifications [50, 63]. We also might speculate that overpressure to the epiphyseal cartilage, exerted by the acetabulum or pelvis owing to the position of the dislocated hip, may cause damage to the femoral epiphysis mainly in older dislocations before any treatment is provided [83].

We report satisfactory long-term results at an average followup of 22 years in a cohort of patients ranging from 3 to 36 months old who had complete DDH reduced by a medial approach. On the basis of the results obtained in our fully grown patients, we believe that open reduction of DDH through a medial approach after preliminary traction can be considered a safe surgical procedure in patients up to the age of 36 months.

\section{References}

1. Akagi S, Tanabe T, Ogawa R. Acetabular development after open reduction for developmental dislocation of the hip: 15-year follow-up of 22 hips without additional surgery. Acta Orthop Scand. 1998;69:17-20.

2. Albinana J, Dolan LA, Spratt KF, Morcuende J, Meyer MD, Weinstein SL. Acetabular dysplasia after treatment of developmental dysplasia of the hip: implications for secondary procedures. J Bone Joint Surg Br. 2004;86:876-886.

3. Alsiddiky AM, Bakarman KA, Alzain KO, Aljassir FF, AlAhaideb AS, Kremli MK, Zanzam MM, Letts RM. The early detection and management of unstable concentric closed reduction of DDH with percutaneous K-wire fixation in infants 6 to 12 months of age. J Pediatr Orthop. 2012;32:64-69.

4. Altay M, Demirkale I, Senturk F, Firat A, Kapicioglu S. Results of medial open reduction of developmental dysplasia of the hip, with regard to walking age. J Pediatr Orthop B. 2013;22:36-41.

5. Angliss R, Fuji G, Pickvance E, Wainwright AM, Benson MK. Surgical treatment of late developmental displacement of the hip: results after 33 years. J.Bone Joint Surg Br. 2005;87:384-394.

6. Bache CE, Graham HK, Dickens RV, Donnan L, Johnson MB, Natrass G, O'Sullivan M, Torode IP. Ligamentum teres tenodesis in medial approach open reduction for developmental dislocation of the hip. J Pediatr Orthop. 2008;28:607-613.

7. Baki C, Sener M, Aydin H, Yildiz M, Sahuran S. Single-stage open reduction through a medial approach and innominate osteotomy in developmental dysplasia of the hip. $J$ Bone Joint Surg Br. 2005;87:380-383.

8. Barlow TG. Early diagnosis and treatment of congenital dislocation of the hip. J Bone Joint Surg Br. 1962;44:292-301.

9. Barrett WP, Staheli LT, Chew DE. The effectiveness of the Salter innominate osteotomy in the treatment of congenital dislocation of the hip. J Bone Joint Surg Am. 1986;68:79-87.

10. Berkeley ME, Dickinson JH, Cain TE, Donovar MM. Surgical therapy for congenital dislocation of the hip in patients who are twelve to thirty-six months old. J Bone Joint Surg Am. 1984;66:412-420.

11. Bicimoglu A, Agus H, Omeroglu H, Tumer Y. Posteromedial limited surgery in developmental dysplasia of the hip. Clin Orthop Relat Res. 2008;466:847-855.

12. Broughton NS, Graham HK, Nattrass GR, Torode IP, Marshall PD, O'Sullivan M. Comment on: Ludloff's medial approach for open reduction of congenital dislocation of the hip. J Bone Joint Surg Br. 1997;79:875-876.

13. Bucholz RW, Ogden JA. Patterns of ischemic necrosis of the proximal femur in nonoperatively treated congenital hip disease. The Hip: Proceedings of the Sixth Open Scientific Meeting of the Hip Society. St Louis, MO: CV Mosby; 1978:43-63.

14. Carroll KL, Murray KA, MacLeod LM, Hennessey TA, Woiczik MR, Roach JW. Measurement of the center edge angle and determination of the Severin classification using digital radiography, computer-assisted measurement tools, and a Severin algorithm: Intraobserver reliability revisited. $J$ Pediatr Orthop. 2011;31:e30-35.

15. Cashman JP, Round J, Taylor G, Clarke NM. The natural history of developmental dysplasia of the hip after early supervised treatment in the Pavlik harness: a prospective, longitudinal follow-up. J Bone Joint Surg Br. 2002;84:418-425.

16. Castillo R, Sherman FC. Medial adductor open reduction for congenital dislocation of the hip. J Pediatr Orthop. 1990;10:335340.

17. Clarke NM, Jowett AJ, Parker L. The surgical treatment of established congenital dislocation of the hip: results of surgery after planned delayed intervention following the appearance of the capital femoral ossific nucleus. J Pediatr Orthop. 2005; 25:434-439.

18. Cordier W, Tönnis D, Kalchschmidt K, Storch KJ, Katthagen BD. Long-term results after reduction of developmental hip dislocation by an anterior approach lateral and medial of the iliopsoas muscle. J Pediatr Orthop Br. 2005;14:79-87.

19. Dezateux C, Godward S. A national survey of screening for congenital dislocation of the hip. Arch Dis Child. 1996;74:445448.

20. Dhar S, Taylor JF, Jones WA, Owen R. Early open reduction for congenital dislocation of the hip. J Bone Joint Surg Br. 1990;72:175-180.

21. Di Mascio L, Carey-Smith R, Tucker K. Open reduction of developmental hip dysplasia using a medial approach: a review of 24 hips. Acta Orthop Belg. 2008;74:343-348.

22. Diepstraten AF. Open reduction of congenital hip dislocation: advantages of the Ferguson medial approach. Acta Orthop Scand. 1985;56:32-35.

23. Doudoulakis JK, Cavadias A. Open reduction of $\mathrm{CDH}$ before one year of age: 69 hips followed for 13 (10-19) years. Acta Orthop Scand. 1993:64:188-192.

24. Gage JR, Winter RB. Avascular necrosis of the capital femoral epiphysis as a complication of closed reduction of congenital dislocation of the hip: a critical review of twenty years' experience at Gillette Children's Hospital. J Bone Joint Surg Am. 1972;54:373-388.

25. Galpin RD, Roach JW, Wenger DR, Herring JA, Birch JG. Onestage treatment of congenital dislocation of the hip in older 
children, including femoral shortening. J Bone Joint Surg Am. 1989;71:734-741.

26. Gardner RO, Bradley CS, Howard A, Narayanan UG, Wedge JH, Kelley SP. The incidence of avascular necrosis and the radiographic outcome following medial open reduction in children with developmental dislocation of the hip: a systematic review. Bone Joint J. 2014;96:279-286.

27. Gibson PH, Benson MK. Congenital dislocation of the hip: review at maturity of 147 hips treated by excision of the limbus and derotation osteotomy. J Bone Joint Surg Br. 1982;64:169-175.

28. Graf R, Tschauner C, Klapsch W. Progress in prevention of late developmental dislocation of the hip by sonographic newborn hip "screening": results of a comparative follow-up study. J Pediatr Orthop. 1993;2:115-121.

29. Grill F, Bensahel H, Canadell J, Dungl P, Matasovic T, Vizkelety $T$. The Pavlik harness in the treatment of congenital dislocating hip: report on a multicenter study of the European Pediatric Orthopaedic Society. J Pediatr Orthop. 1988;8:1-8.

30. Gulman B, Tunkay IC, Dobak N, Karaismailoglu N. Salter's innominate osteotomy in the treatment of congenital hip dislocation: a long-term study. J Pediatr Orthop. 1994;14:662-666.

31. Haidar RK, Jones RS, Vergroesen DA, Evans GA. Simultaneous open reduction and Salter innominate osteotomy for developmental dysplasia of the hip. J Bone Joint Surg Br. 1996;78:471-476.

32. Harris $\mathrm{NH}$. Acetabular growth potential in congenital dislocation of the hip and some factors upon which it may depend. Clin Orthop Relat Res. 1976;119:99-106.

33. Holman J, Carroll KL, Murray KA, Macleod LM, Roach JW. Long-term follow-up of open reduction surgery for developmental dislocation of the hip. J Pediatr Orthop. 2012;32:121-124.

34. Huber H, Mainard-Simard L, Lascombes P, Renaud F, JeanBaptiste M, Journeau P. Normal values of bony, cartilaginous, and labral coverage of the infant hip in MR imaging. $J$ Pediatr Orthop. 2014;34:674-678.

35. Kahle WK, Anderson MB, Alpert J, Stevens P, Coleman SS. The value of preliminary traction in the treatment of congenital dislocation of the hip. J Bone Joint Surg Am. 1990;72:1043-1047.

36. Kalamchi A, Schmidt TL, MacEwen GD. Congenital dislocation of the hip: open reduction by the medial approach. Clin Orthop Relat Res. 1982;169:127-132.

37. Kiely N, Younis U, Day JB, Meadows TM. The Ferguson medial approach for open reduction of developmental dysplasia of the hip: a clinical and radiological review of 49 hips. J Bone Joint Surg Br. 2004;86:430-433.

38. Kim HW, Morcuende JA, Dolan LA, Weinstein SL. Acetabular development in developmental dysplasia of the hip complicated by lateral growth disturbance of the capital femoral epiphysis. $J$ Bone Joint Surg Am. 2000;82:1692-1700.

39. Koizumi W, Moriya H, Tsuchiya K, Takeuchi T, Kamegaya M, Akita T. Ludloff's medial approach for open reduction of congenital dislocation of the hip: a 20-year follow-up. $J$ Bone Joint Surg Br. 1996;78:924-929.

40. Konigsberg DE, Karol LA, Colby S, O'Brian S. Results of medial open reduction of the hip in infants with developmental dislocation of the hip. J Pediatr Orthop. 2003;23:1-9.

41. Lehman WB, Grant AD, Nelson J, Robbins H, Milgram J. Hospital for Joint Diseases' traction system for preliminary treatment of congenital dislocation of the hip. J Pediatr Orthop. 1983;3:104-107.

42. Lequesne M, de Sèze S. [False profile of the pelvis: a new radiographic incidence for the study of the hip. Its use in dysplasias and different coxopathies][in French]. Rev Rhum Mal Osteoartic. 1961;28:643-652.

43. Lindstrom JR, Ponseti IV, Wenger DR. Acetabular development after reduction in congenital dislocation of the hip. J Bone Joint Surg Am. 1979;61:112-118.
44. Luhmann SJ, Schoenecker PL, Anderson AM, Bassett GS. The prognostic importance of the ossific nucleus in the treatment of congenital dysplasia of the hip. J Bone Joint Surg Am. 1998; 80:1719-1727.

45. Madhu TS, Akula M, Scott BW, Templeton PA. Treatment of developmental dislocation of hip: does changing the hip abduction angle in the hip spica affect the rate of avascular necrosis of the femoral head? J Pediatr Orthop Br. 2013;22:184-188.

46. Mankey MG, Arntz GT, Staheli LT. Open reduction through a medial approach for congenital dislocation of the hip: a critical review of the Ludloff approach in sixty-six hips. J Bone Joint Surg Am. 1993;75:1334-1345.

47. Mardam-Bey TH, MacEwen GD. Congenital hip dislocation after walking age. J Pediatr Orthop. 1982;2:478-486.

48. Matsushita T, Miyake Y, Akazawa H, Eguchi S, Takahashi Y. Open reduction for congenital dislocation of the hip: comparison of the long-term results of the wide exposure method and Ludloff's method. J Orthop Sci. 1999;4:333-341.

49. Mergen E, Adyaman S, Omeroglu H, Erdemli B, Isiklar U. Medial approach open reduction for congenital dislocation of the hip using the Ferguson procedure: a review of 31 hips. Arch Orthop Trauma Surg. 1991;110:169-172.

50. Morcuende JA, Meyer MD, Dolan LA, Weinstein SL. Long-term outcome after open reduction through an anteromedial approach for congenital dislocation of the hip. J Bone Joint Surg Am. 1997;79:810-817.

51. Morin C, Bisogno J, Kulkarni S, Morel G. Treatment of latepresenting developmental dislocation of the hip by progressive orthopaedic reduction and innominate osteotomy: our results with more than 30 years of follow up. J Child Orthop. 2011;5:251-260.

52. O'Hara JN, Bernard AA, Dwyer NS. Early results of medial approach open reduction in congenital dislocation of the hip: use before walking age. J Pediatr Orthop. 1988;8:288-294.

53. Okano K, Enomoto H, Osaki M, Takahashi K, Shindo H. Femoral head deformity after open reduction by Ludloff's medial approach. Clin Orthop Relat Res. 2008;466:2507-2512.

54. Okano K, Yamada K, Takahashi K, Enomoto H, Osaki M, Shindo H. Long-term outcome of Ludloff's medial approach for open reduction of developmental dislocation of the hip in relation to the age at operation. Int Orthop. 2009;33:1391-1396.

55. Ortolani M. Un segno poco noto e sua importanza per la diagnosi precoce di prelussazione congenita dell'anca. Pediatria. 1937;45:129-136.

56. Ponseti IV. Morphology of the acetabulum in congenital dislocation of the hip: gross, histological and roentgenographic studies. J Bone Joint Surg Am. 1978;60:586-599.

57. Pospischill R, Weninger J, Ganger R, Altenhuber J, Grill F. Does open reduction of the developmental dislocated hip increase the risk of osteonecrosis? Clin Orthop Relat Res. 2012;470:250-260.

58. Powell EN, Gerratana FJ, Gage JR. Open reduction for congenital hip dislocation: the risk of avascular necrosis with three different approaches. J Pediatr Orthop. 1986;6:127-132.

59. Quinn RH, Renshaw TS, DeLuca P. Preliminary traction in the treatment of developmental dislocation of the hip. J Pediatr Orthop. 1994;14:636-642.

60. Roose PE, Chingren GL, Klaaren HE, Broock G. Open reduction for congenital dislocation of the hip using the Ferguson procedure: a review of twenty-six cases. J Bone Joint Surg Am. 1979;61:915-921.

61. Roposch A, Liu LQ, Offiah AC, Wedge JH. Functional outcomes in children with osteonecrosis secondary to treatment of developmental dysplasia of the hip. J Bone Joint Surg Am. 2011; 93:e145.

62. Roposch A, Stöhr KK, Dobson M. The effect of the femoral head ossific nucleus in the treatment of developmental dysplasia of the hip: a meta-analysis. J Bone Joint Surg Am. 2009;91:911-918. 
63. Roposch A, Wedge JH, Riedl G. Reliability of Bucholz and Hodgen classification for osteonecrosis secondary to developmental dysplasia of the hip. Clin Orthop Relat Res. 2012;470:3499-3505.

64. Schoenecker PL, Strecker WB. Congenital dislocation of the hip in children: comparison of the effects of femoral shortening and of skeletal traction in treatment. J Bone Joint Surg Am. 1984;66:21-27.

65. Segal LS, Boal AK, Borthwick L, Clark MW, Localio AR, Schwentker EP. Avascular necrosis after treatment of DDH: the prospective influence of the ossific nucleus. J Pediatr Orthop. 1999;19:177-184.

66. Severin E. Contribution to the knowledge of congenital dislocation of the hip joint: late results of closed reduction and arthrographic studies of recent cases. Acta Chir Scand. 1941;84(suppl 63):1-142.

67. Sharp IK. Acetabular dysplasia: the acetabular angle. $J$ Bone Joint Surg Br. 1961;43:268-272.

68. Smith WS, Badgley CE, Orwing JB, Harper JM. Correlation of post-reduction roentgenograms and thirty-one-year follow-up in congenital dislocation of the hip. J Bone Joint Surg Am. 1968;50:1081-1098.

69. Sosna A, Rejholec M. Ludloff's open reduction of the hip: longterm results. J Pediatr Orthop. 1992;12:603-606.

70. Szepesi K, Biro B, Fazekas K, Szucs G. Preliminary results of early open reduction by an anterior approach for congenital dislocation of the hip. J Pediatr Orthop B. 1995;4:171-178.

71. Szepesi K, Szucs G, Szeverenyi C, Csernatony Z. Long-term followup of DDH patients who underwent open reduction without a postoperative cast. J Pediatr Orthop B. 2013;22:85-90.

72. Tarassoli P, Gargan MF, Atherton WG, Thomas SR. The medial approach for the treatment of children with developmental dysplasia of the hip. Bone Joint J. 2014;96:406-413.

73. Thomas IH, Dunin AJ, Cole WG, Menelaus MB. Avascular necrosis after open reduction for congenital dislocation of the hip: analysis of causative factors and natural history. J Pediatr Orthop. 1989;9:525-531.

74. Thomas SR, Wedge JH, Salter RB. Outcome at forty-five years after open reduction and innominate osteotomy for late-presenting developmental dislocation of the hip. J Bone Joint Surg Am. 2007;89:2341-2350.

75. Tönnis D. Congenital Dysplasia and Dislocation of the Hip in Children and Adults. Legal H, Graf R, collaborators; Telger TC, translator. Berlin, Germany: Springer-Verlag; 1987.
76. Tönnis D, Behrens K, Tscharani F. A modified technique of the triple pelvic osteotomy: early results. J Pediatr Orthop. 1981; 1:241-249.

77. Tumer Y, Ward T, Grudziak J. Medial open reduction in the treatment of developmental dislocation of the hip. $J$ Pediatr Orthop. 1997;17:176-180.

78. Ucar DH, Isiklar ZU, Stanitski CL, Kandemir U, Tumer Y. Open reduction through a medial approach in developmental dislocation of the hip: a follow-up study to skeletal maturity. J Pediatr Orthop. 2004;24:493-500.

79. Varner KE, Incavo SJ, Haynes RJ Dickson JH. Surgical treatment of developmental hip dislocation in children aged 1 to 3 years: a mean 18-years, 9-month follow-up study. Orthopedics. 2010;10:162-166.

80. Wang TM, Wu KW, Shih SF, Huang SC, Kuo KN. Outcomes of open reduction for developmental dysplasia of the hip: does bilateral dysplasia have a poorer outcome? J Bone Joint Surg Am. 2013;95:1081-1086.

81. Weinstein SL. Congenital hip dislocation: long-range problems, residual signs, and symptoms after successful treatment. Clin Orthop Relat Res. 1992;281:69-74.

82. Weinstein SL. Traction in developmental dislocation of the hip: is its use justified? Clin Orthop Relat Res. 1997;338:79-85.

83. Weinstein SL. CORR insights: Reliability of Bucholz and Ogden classification for osteonecrosis secondary to developmental dysplasia of the hip. Clin Orthop Relat Res. 2012;470;3506-3507.

84. Weinstein SL. Developmental hip dysplasia and dislocation. In: Weinstein SL, Flynn JM, eds. Lovell and Winter's Pediatric Orthopaedics. 7th ed. Philadelphia, PA: Lippincott Williams and Wilkins; 2014:983-1111.

85. Weinstein SL, Ponseti IV. Congenital dislocation of the hip. J Bone Joint Surg Am. 1979;61:119-124.

86. Wiberg G. Studies on dysplastic acetabula and congenital subluxation of the hip joint with special reference to the complication of osteoarthritis. Acta Chir Scand. 1939;83(suppl 58):53-68.

87. Wirth T, Stratmann L, Hinrichs F. Evolution of late presenting developmental dysplasia of the hip and associated surgical procedures after 14 years of neonatal ultrasound screening. $J$ Bone Joint Surg Br. 2004;86:585-589.

88. Zamzam MM, Khoshhal KI, Abak AA, Bakarman KA, Alsiddiky AM, AlZain KO, Kremli MK. One-stage bilateral open reduction through a medial approach in developmental dysplasia of the hip. J Bone Joint Surg Br. 2009;91:113-118. 